めてあたり前の事で,「自律史観」とその事は決して矛盾はしないはずである。しか し, そうした外文明の受容を認めた上で, それならば何故東南アジアは今に至るまで, 逆に外世界に十分影響を与えるほどの高度な自己の文化を生み出す事が出来なかった のかという事も真剣に問われなければならない。さらに文化の発展がある程度の凝集 力を前提とするものならば, そもそも東南アジアを一つのものとして括る考え方が本 当に正しいのかという根本的な問題に立ち返る必要もあろう。このような点にまだま だ拘らなければならない段階にあるのが東南アジア史研究であり, 本書にも善かれ悪 しかれその事が反映されているのである。まずは御一読を。

吉川利治 著

『泰緬鉄道一機密が明かすアジア太平洋戦争—』

同文館 1994 年 352 頁

\title{
黒田 景子
}

『泰緬鉄道』の名は昭和 30 年代生まれの評者にとって, 太平洋戦争下で日本軍がアジ アにおいて行った様々な「非人道的行為」のイメージと固く結びついている。

評者がこの鉄道の名を知ったのは, デビット・リーン監督による映画「戦場にかけ る橋」によってであり,この映画は泰緬鉄道の橋脚建設労働を強制され, 劣悪な労働 環境のもとで, 日本兵による非人道的な扱いに耐えつつ生き残った連合軍捕虜の姿を 描いたものである。『戦場にかける橋』は有名な「クワイ川マーチ」のメロディととも に, 戦争映画の名作として数々の賞をとり, いまだに何度も放映される。その舞台の 橋はいまやカンチャナブリーの重要な観光資源であり, 観光客は, 土産物屋の間を擦 り抜けながら鉄橋をむこう岸にわたってみたり，捕虜が収容されていた粗末な小屋を 復元し資料を展示した博物館や緑の芝生に整然とならんだ戦没犠牲者墓地を訪れたり することになる。

泰緬鉄道は太平洋戦争のさなか1942年から 1 年という短期間の工期で夕イ（泰）と ビルマ（緬）の国境地帯のジャングルを切り開いて作られた。建設には多大な困難を 伴い, また建設工事にあたって徵用された連合軍捕虜や現地のアジア人労働者に多数 の死者をだして「死の鉄道」と呼ばれ非難された。戦後, 労働を強制され多くの死者 
をだした連合国側のイギリス・オーストラリア・オランダの各国は，日本軍の関係者 を告発し戦争裁判によって処断し，泰緬鉄道の「悪名」は世界に知られることになる。

ところで，泰緬鉄道については生還した連合軍捕虜の手記や鉄道建設にあたつた日 本軍鉄道隊の手記が多数存在しているが，いずれも私的な経験にもとづくある意味で は断片的なものでしかなかった。全体像を描いたものとしては不足している部分を感 じざるをえなかったが，それは，鉄道の計画・建設・運営に関する公的な一次資料か らの検討が欠けているためであり，これらの資料は日本軍が後難を恐れて焼却したと もいわれてきたのである。

ところが，タイ国立公文書館には，日本軍駐屯によって生じたさまざまな事態の報 告書や命令文書，会議録などという，日本側からだされた日本語の文書をふくむ国家 の最高機密文書が一部保存されており, それがこのたび著者によってはじめて公開さ れることになった。本書は,この現存する唯一の一次資料一一イ国立公文書館蔵の タイ国軍最高司令部公文書一一を駆使して泰緬鉄道の全体像をとらえた力作である。

さて，本書には以下のように目次がつけられている。

1 南方へ向かう日本軍鉄道隊

2 泰緬鉄道建設計画

3 ビルマ占領とタイとの建設交涉

4 泰緬鉄道は軍用か民用か

5 鉄道隊の組織と建設用地

6 夕イ人労務者とバーンポーン事件

7 連合国捕虜

8 捕虜の行軍と労働

9 疫病に倒れる捕虜

10 タイ国内外のアジア人労務者

11 クラ地峡横断鉄道

12 泰緬鉄道完工のころの日本軍・捕虜・労務者

13 泰緬鉄道の運行と規模

14 戦後の泰緬鉄道と戦争裁判

本書の内容は多岐にわたり，ここではその一部を概略するにとどめる。まず，本書 の前半では，泰緬鉄道建設構想をめぐる，日本軍の思惑と，それに対する「独立国」 タイとの駆け引きが述べられている。

著者は，日本陸軍が泰緬鉄道建設の構想をアジア太平洋戦争勃発直前にすでにもっ 
ており，作戦地に鉄道を建設することで，戦時は軍用に，平時においては民用に供し， しかもその鉄道の権益は戦後も確保しておいて満鉄に移管するという「満鉄方式」を, 泰緬鉄道の場合にも踏襲しょうとしていたとみる。そして, ビルマ作戦がシンガポー ル陥落以前に進行し, 占領地域が拡大するのと逆に, 日本が太平洋海戦で多くの輸送 船を失い, 陸上輸送路の確保が必要になると, 建設が困難であると一部では諦められ かけた泰緬鉄道の建設に着手せざるを得なくなったとみる。

日本軍は泰緬鉄道建設にあたつては，独立国である夕イとの間に鉄道敷設の許可を 求めなければならなかった。一方，夕イは基本的にこれを許可すると同時にこの泰緬 鉄道をあくまで自国に所属する鉄道として確保したいと思い，工事を急ぐ日本軍に疑 念をいだきながらも，あくまで「泰緬鉄道は作戦用の軍用鉄道である」という回答を 日本側から引き出そうとした。著者は夕イが, 鉄道経営の権益取得が帝国主義者の植 民地獲得の手段であることを知っており，泰緬鉄道を日本の権益が生まれないように 軍用鉄道という性格にしておくために，その建設には参加しておく必要があったとす る。

また，実際の日本軍の鉄道建設については，牽引の機関車以外の設備はほとんど現 地調達の建設機材であり, ジャワ鉄道やマラヤ鉄道などから資材を調達するものであ った。また，労働力においても，連合軍の捕虜をあてたが，まっとうな機材もなく， また雨期の熱帯の密林での不衛生な環境で激務を強いたため, きわめて多くの死者を だした。暴行や拷問などの捕虜に対する非人道的な扱いと苛酷な労働は, 生還した捕 虜の手記によって生々しく描写され, 告発されている。戦後の戦争裁判では, 泰緬鉄 道の関係者に多くの処刑者がでている。また，1943年 2 月に大本営から 4 箇月の工期 短縮命令がでると, 人海戦術として現地のアジア人労務者をかき集めて, やはり同じ 悪条件のもとで建設は続行された。タイの資料によると，このときかき集められたア ジア人労務者はまず, 夕イの華僑, タイ人, ビルマ人, そしてマラヤからつれてこら れたマレー人, ジャワ人, インド人であるという。労務者には捕虜と異なって, 給料 が支払われたが, 連れてこられる間に逃亡するものも多く，その死亡率も 40 パーセン トをこえる場合があった。「泰緬鉄道建設が世界に悪名を馳せる結果となるのも, 無理 に無理をかさね, 精神で克服しようとして陥った非人間性のゆえであった」と著者は 断罪する。

本書は, 『戦陣訓』の中の「生きて虜囚の辱を受けず」という文言が「捕虜になるよ うな人間は侮茂されるべきである」という理屈につながり, 連合軍捕虜への暴行, 虐 待, 拷問につながったと述べ,「泰緬鉄道の建設は, ヨーロッパ列強を範として追いか 
け追い付こうとした明治以来の近代化の帰結を示すものであったが，列強を駆除する 段階においては, 近代文明の精神を廃絶して, 国粋主義を旨とする軍国時代の日本の 精神を具現するものになっていた」としめくくられる。

しかしながら，本書の価値は，日本軍対連合国軍の図式のなかで語られがちな「泰 緬鉄道」の物語に，そのそばでじっと見据えていた夕イの人々の存在をなまなましく 付け足したことにある。

Mayoury and Pheuiphanh Ngaosyvathn

Kith and Kin Politics: The Relationship between Laos and Thailand Journal of Contemporary Asia Publishers, Manila, 1994. 137 pages.

\section{小泉 順子}

チャートチャーイ首相（在1988-1991）がインドシナ地域の戦場から市場への転換 を提唱し，また近隣社会主義諸国が経済の自由化政策を進めつつある中，タイと近隣 の社会主義諸国との経済的関係の緊密化が当事国ばかりでなく日本などでも熱い注目 を集めつつある。本書は，こうしてつながりを強めつつあるラオス＝タイ関係を歴史 的に振り返り, その「愛憎入り交じる複雑さ」を明らかにすることにより, 今後の両 国間の対話と理解に貢献することを目的としてまとめられたものである。著者である マュリーとプエイパンは，ともにパリ大学で博士号を取得し，1975年以降約10年にわ たって官僚としてラオスの行政の実務に携わった後, 米国, シンガポールなどで研究 を積んだ経歴を持つ。現在はオーストラリアの Griffis 大学にて教鞭をとり,ラオス =タ イ関係について, 文化・歴史なども含めた幅広い分野で多数の論文を発表してきてい る。本書は彼らが過去 4,5 年の間に学会や雑誌で発表した論文を新たに 1 冊に編み 直したものである。

本書は次の 5 章と, 短い序章および結論から成る。第 1 章, 第 2 章では, ラオが18 世紀末にシャムの「朝貢国」とされるまで独立王国を保ち, その後政治的変化の中で 今日まで独自の文化を保持し続けてきたことが確認され，今日タイ側のラオス認識 —タイの「弟」国としての扱いやラオ文化に対する䓏視——との間に横たわるギャ ップが示される。第 3 章は1950年代から90年代初めまでのラオス $=$ タイ経済関係を扱 